\title{
Latest Pleistocene to Holocene changes in glaciomarine sedimentation in Scoresby Sund and along the adjacent East Greenland Continental Margin: Preliminary results
}

Received 22 May 1992 / Revision received 4 October 1992

\begin{abstract}
Based on preliminary results of sedimentological and organic geochemical investigations, distinct changes in the composition of siliciclastic and biogenic components occured in sediments from the East Greenland Continental Slope and Shelf and Scoresby Sund during the latest Pleistocene to Holocene times. These changes probably reflect the (? early/) late Weichselian glacial to Holocene interglacial transition, i.e., the decay of continental ice masses and sea-ice cover, causing major changes in supply of terrigenous matter and surface-water productivity. Flux rates of coarse-grained ice-rafted debris (IRD) distinctly decreased on the continental slope/shelf during the deglaciation interval. During the last 10,000 years, major amounts of IRD were trapped in the Scoresby Sund system. In comparison to modern interglacial conditions, surface-water productivity was significantly lower during the last glacial.
\end{abstract}

\section{Introduction and objectives}

High-latitude areas are very sensitive to paleoenvironmental changes, as shown in the landmark study of the CLIMAP (Climate Long Range Investigation Mapping and Prediction) group for the latest Pleistocene glacialHolocene interglacial cycle (CLIMAP 1981). Thus, detailed sedimentological and organic-geochemical studies of marine sediments from the East Greenland Continental Margin (Fig. 1) can yield important information about the glacial-interglacial variations of paleoenvironment.

Sedimentary processes, terrigenous sediment supply, and biogenic productivity in the study area are mainly influenced by fluctuations in the extent of the Greenland Ice Sheet, extent of sea ice, rate of drifting icebergs, meltwater input, and/or oceanic circulation (Fig. 2), i.e., all

R. Stein $\cdot$ H. Grobe $\cdot$ H. Hubberten - P. Marienfeld $\cdot$ S. Nam Alfred-Wegener-Institute for Polar and Marine Research, Bremerhaven, Germany factors controlled by climate. The reconstruction of this environmental history of the East Greenland Margin and the correlation between terrestrial and marine records are major objectives of the ESF-PONAM (European Science Foundation-Polar North Atlantic Margins) program (Elverhoi and Dowdeswell 1991). Although terrestrial fieldwork on eastern Greenland (e.g., Hjort 1981; Funder 1984; Möller and others 1991, and references therein) and

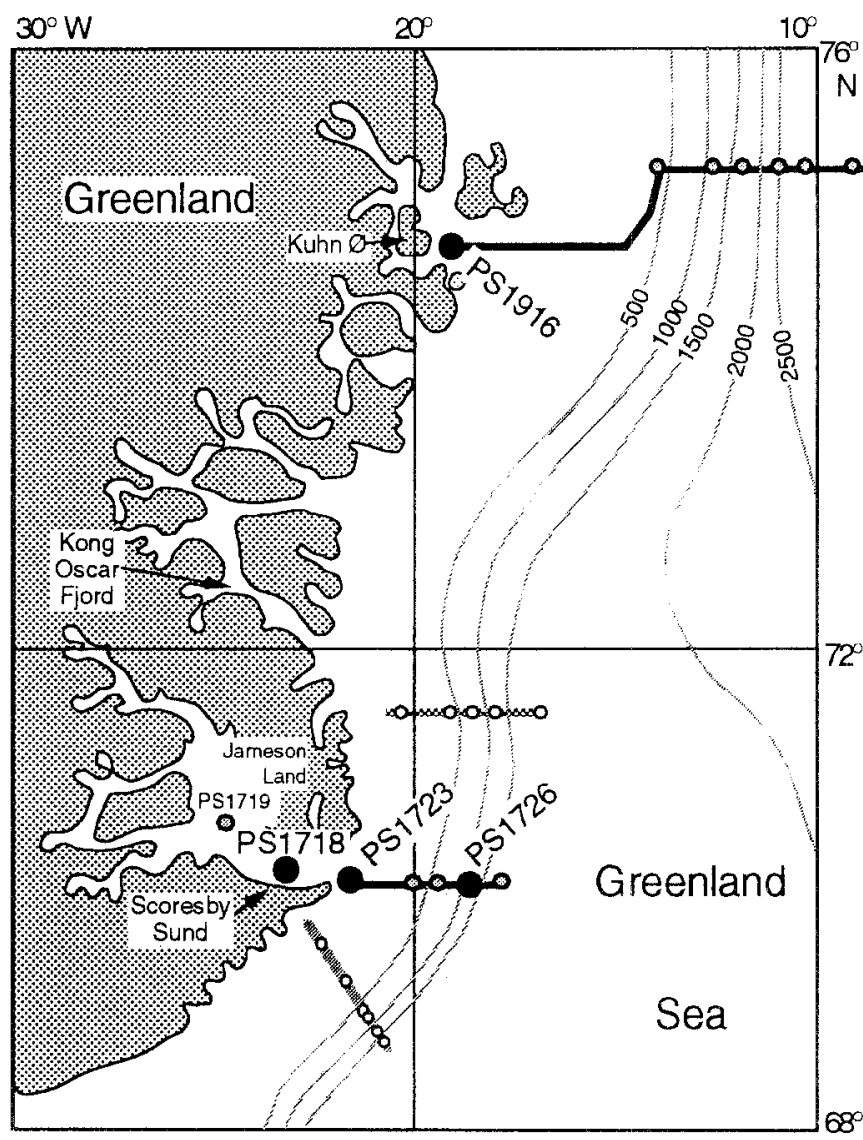

Fig. 1. Study area and location of core profiles at the East Greenland Continental Margin and Scoresby Sund area. In this paper, results from investigations of sediments from cores PS1718, PS1723, PS1726, and PS1916 are presented 


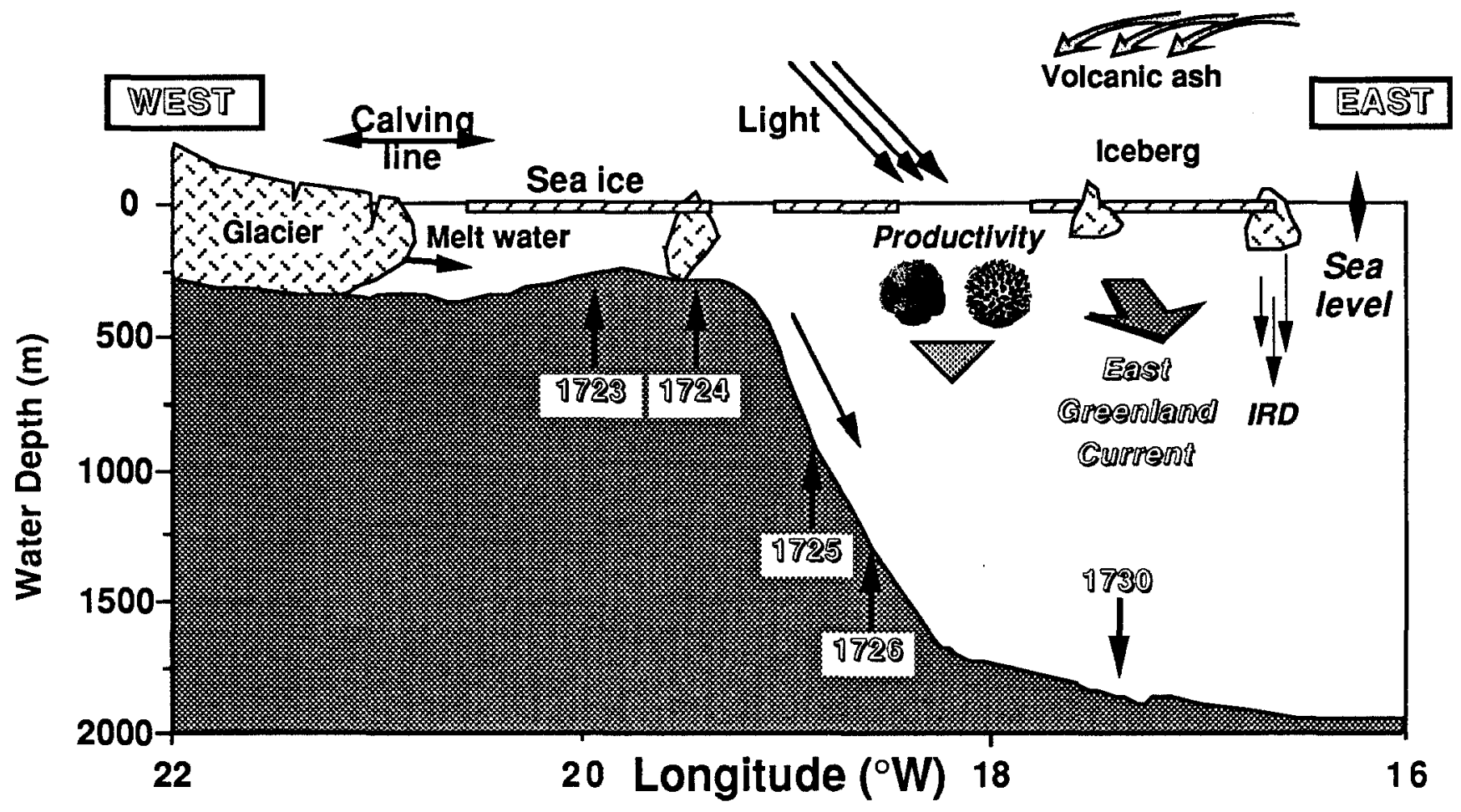

Fig. 2. Simplified scheme of the continental margin profile of cores PS1723-PS1730, indicating the major climatic and oceanographic factors and processes controlling the sedimentation along the East Greenland Continental Margin

numerous investigations performed on marine sediments from the Norwegian-Greenland Sea (e.g., Henrich and others 1989; Bohrmann and others 1990; Gard and Backman 1990; Vogelsang 1990) gave important information about changes in paleoclimate during the last glacialinterglacial cycles, major problems arise when correlating the terrestrial (and fjord) and deep-sea records. In order to link these terrestrial and marine paleoclimatic records, we started to study sediment cores taken along profiles from Scoresby Sund, the Eastern Greenland shelf and slope, down to the deep sea (Fig. 1)

\section{Materials and methods}

Sediments were recovered by gravity coring on profiles perpendicular to the East Greenland Continental Margin between about $69^{\circ}$ and $75^{\circ} \mathrm{N}$ and in the Scoresby Sund during POLARSTERN expeditions ARK V/3 and ARK VII/3 in 1988 and 1990, respectively. The coring positions have been carefully selected based on Parasound and Hydrosweep profiling. The water depths of cores vary between about 280 and $3200 \mathrm{~m}$. The age represented in the sedimentary sequences is latest Pleistocene (postglacial) to Holocene in the Scoresby Sund cores, based on ${ }^{14} \mathrm{C}$ ages (Marienfeld 1991), and late Quaternary in the East Greenland Margin cores, based on oxygen stable isotope records and tephra- and lithostratigraphy (Nam and others in preparation).

The study is based on the following methods: detailed description of lithology to identify sediment facies types; separation of clay, silt, sand, and gravel fractions; detailed coarse fraction analysis (determination of biogenic and siliciclastic components); oxygen and carbon isotope measurements; X-ray diffraction (bulk and clay mineralogy); determination of carbonate, organic carbon, and nitrogen contents; and classiffcation of the organic carbon fraction using Rock-Eval pyrolysis (i.e., hydrogen and oxygen index values) and $\mathrm{C} / \mathrm{N}$ ratios. Details in methodology are described in Grobe and others (1990), Marienfeld (1991), and Stein (1991).

\section{Results}

In this paper, preliminary results from selected sediment sequences from the East Greenland Continental Margin

Fig. 3a-d. Results from three selected sediment cores from the profile at $70^{\circ} \mathrm{N}$ : a slope core PS1726-1, b shelf core PS1723-1, and c Scoresby Sund core PS1718-1. In addition, the results from the shelf core PS1916-1 at $75^{\circ} \mathrm{N}$ are also shown d. For all four cores, lithologies, amount of ice-rafted debris (IRD, i.e., gravel fraction $>2 \mathrm{~mm}$, counted in X-radiographs and expressed as numbers per $10 \mathrm{~cm}^{3}$ ), contents of carbonate and organic carbon, organic carbon/nitrogen $(\mathrm{C} / \mathrm{N})$ ratios, and hydrogen index $(\mathrm{HI})$ values $(\mathrm{HI}$ expressed as milligrams of hydrocarbon per gram organic carbon) are shown. $\mathrm{C} / \mathrm{N}$ ratios and $\mathrm{HI}$ values allow a first characterization of the organic matter, with $\mathrm{C} / \mathrm{N}$ ratios of $<10$ and $\mathrm{HI}$ values of $\gg 100$ typical for marine organic matter and $\mathrm{C} / \mathrm{N}$ ratios $>15$ and $\mathrm{HI}$ values $<100$ typical for terrigenous organic matter (for details see Stein 1991). For further explanations see text 


\section{Profile $70^{\circ} \mathrm{N}$}

\section{a. Slope (PS 1726-1)}

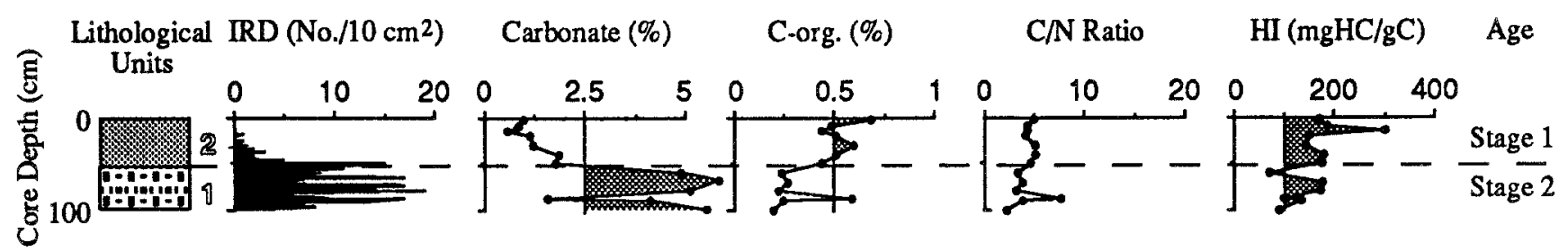

\section{b. Shelf (PS 1723-1)}

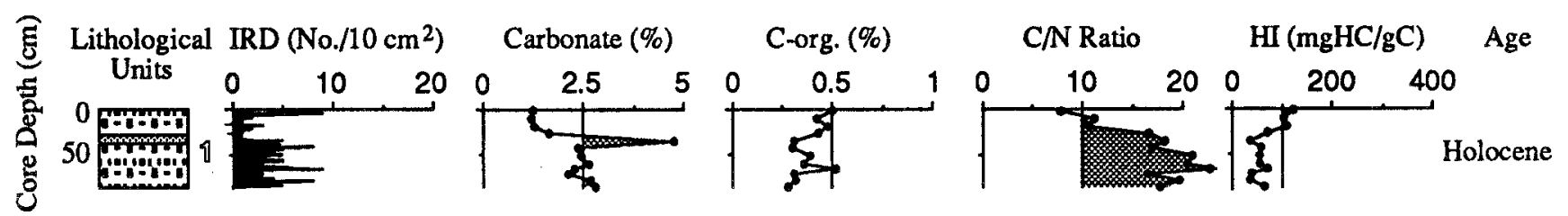

\section{c. Scoresby Sund (PS 1718-1)}

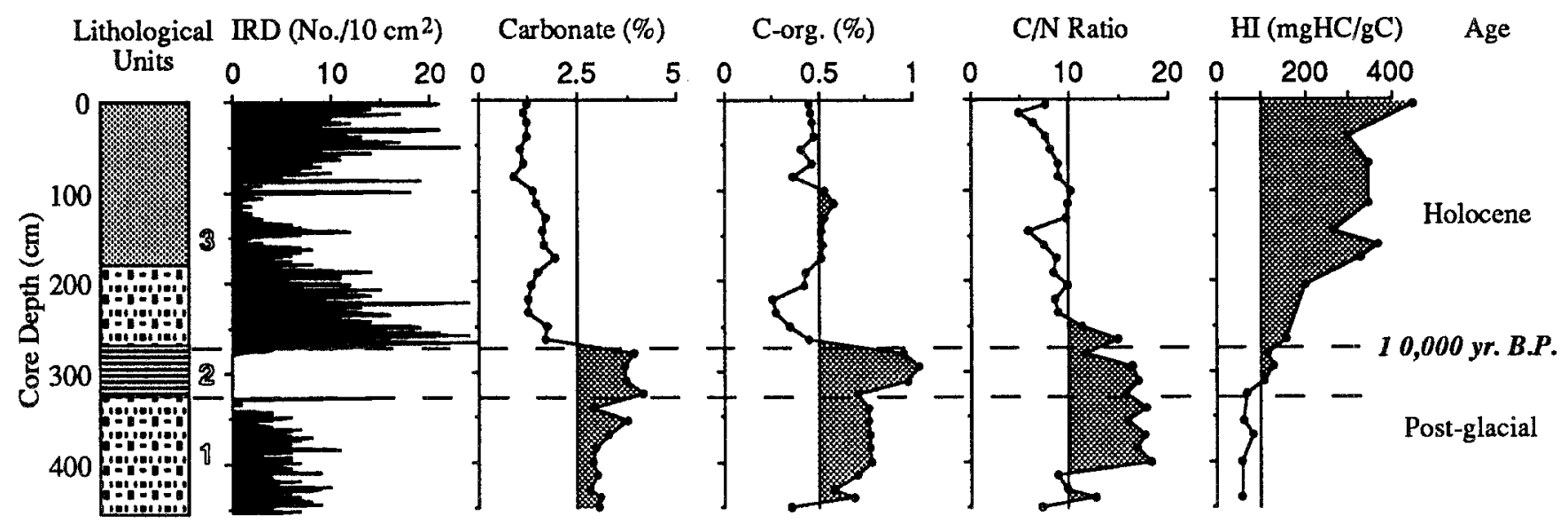

\section{Profile $75^{\circ} \mathrm{N}$}

\section{d. Shelf (PS 1916-1)}

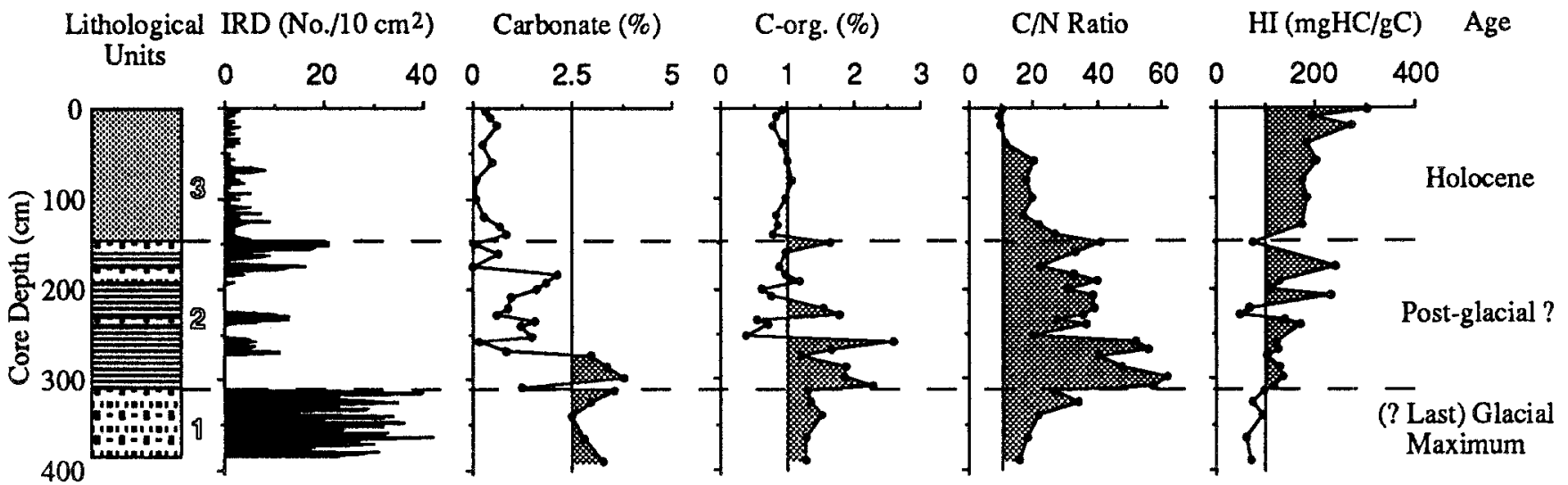


profile at $70^{\circ} \mathrm{N}$ (Figs. 1 and 2), representing the latest Pleistocene to Holocene interval, are presented and discussed below (Fig. 3a-c). The penetration of the gravity corer was very low on the shelf off Scoresby Sund $(85 \mathrm{~cm})$, probably caused by underlying till and/or high amounts of gravel-sized material preventing further penetration of the coring gear. Thus, the use of the stratigraphic shelf record off Scoresby Sund is limited and a shelf record from the profile at $75^{\circ} \mathrm{N}$ (Fig. 1) is also included to this report (Fig. 3d).

\section{Upper slope record: Core PS1726-1}

Core PS1726 is situated at the East Greenland Continental Slope in a water depth of $1174 \mathrm{~m}$ (Fig. 1). The sediments are mainly composed of brownish gray to olive silty clay with varying amounts of sand- and gravel-sized siliciclastic components. Based on stable oxygen isotopes and the ash layer at $40 \mathrm{~cm}$ depth (Fig. 3a), the upper $100 \mathrm{~cm}$ of the sediment sequence probably represent the last 30,000 years (see Nam and others, in preparation, for the long-term Quaternary glacial-interglacial record). This upper interval can be divided into two lithological units (Fig. 3a). The lower unit 1 (sandy mud) is characterized by high amounts of coarse-grained ice-rafted debris (IRD), relatively high contents of biogenic carbonate $(4-7 \%$ ) (mainly foraminifera), and low contents of organic carbon of about $0.25 \%$.
Unit 2 (clayey silt), on the other hand, is characterized by the almost complete absence of IRD, very low carbonate contents $(<2 \%)$, and increased organic carbon contents $(0.4-0.7 \%)$. Preliminary information about the composition of the organic carbon fractions can be derived from organic carbon-nitrogen $(\mathrm{C} / \mathrm{N})$ ratios and hydrogen index values (cf., Stein 1991). Low C/N ratios of 3-5 (Fig. 3a) suggest the preservation of major amounts of marine organic matter. The single $\mathrm{C} / \mathrm{N}$ maximum coinciding with a high organic carbon value may indicate an event of increased input of terrigenous organic matter. The $\mathrm{C} / \mathrm{N}$ ratios of core PS1726, however, have to be interpreted with caution because in the organic-carbon-poor sediments of this core the amount of inorganic nitrogen (fixed as ammonium ions in the interlayers of clay minerals, especially illite) may become a major portion of the total nitrogen, causing (too) low C/N ratios (cf., Müller 1977; Stein 1991). Hydrogen index values of 100-300 support a mixture between terrigenous and marine organic matter, with some higher amounts of terrigenous material in the sediments of unit 1 and some higher amounts of marine material in sediments of unit 2 (Figs. 3a, 4a). The sand-sized siliciclastic sediment components in both units are dominated by quartz; feldspars, mica, and rock fragments occur in minor, but significant, amounts (Nam and others in preparation). The prominent decrease in the amount of IRD, the increase in organic carbon, and the decrease in carbonate at about
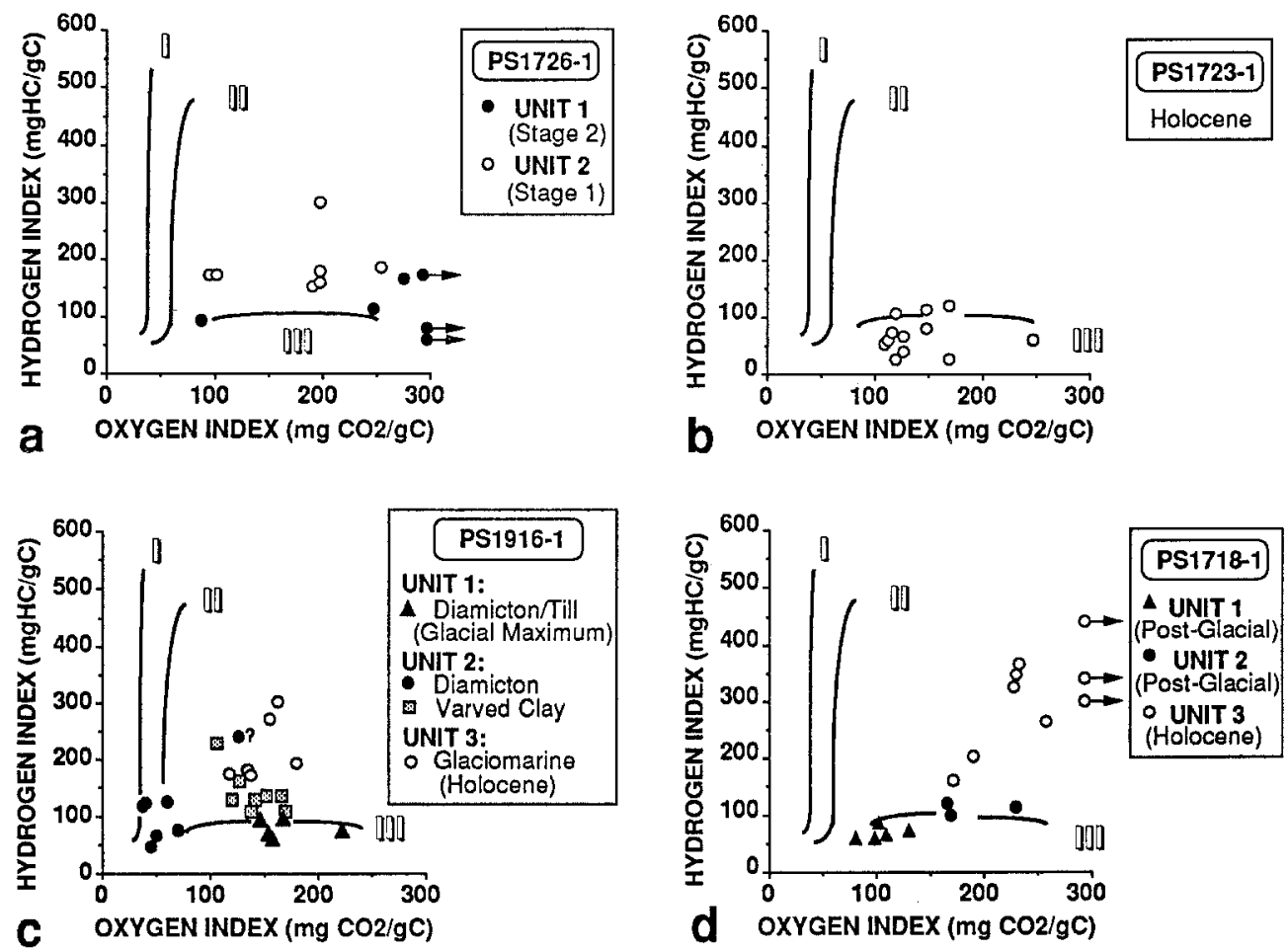

Fig. 4a-d. Results of Rock-Eval pyrolysis measurements of sediments from cores PS1726-1 a, PS1723-1 b, PS1916-1 c, and PS1718-1 d, shown in a hydrogen vs. oxygen index-type (HI-OI) diagram which is useful to distinguish between types of (immature) organic matter. Organic matter of type I and II (i.e., high hydrogen and low oxygen index values) is marine, type III (i.e., low hydrogen and high oxygen index values) is terrigenous. Data points falling between fields II and III indicate a mixture of terrigenous and marine organic matter. During the increasing stage of maturity (i.e., during its evolution path), organic matter loses oxygen and hydrogen, resulting in low hydrogen and low oxygen index values. That means data points derived from mature organic matter samples fall close to the origin in the HI-OI diagram. In this case, a distinction between marine and terrigenous source is not possible from Rock-Eval data (for details of method see Tissot and Welte 1984) 
$50 \mathrm{~cm}$ depth probably represent the transition from the last glacial maximum conditions (unit 1, i.e., oxygen isotope stage 2) to the postglacial-Holocene interglacial conditions (unit 2, i.e., oxygen isotope stage 1) (Fig. 3a). Based on stable isotope data, estimated mean sedimentation rates are $4.8 \mathrm{~cm} / \mathrm{ka}$ for unit 1 and $3.7 \mathrm{~cm} / \mathrm{ka}$ for unit 2 (Nam and others in preparation). AMS ${ }^{14} \mathrm{C}$ dating is in progress to prove these estimates.

\section{Shelf record: Cores PS1723-1 and PS1916-1}

Core PS1723, located on the shelf directly off Scoresby Sund in a water depth of $283 \mathrm{~m}$, has a total length of only $85 \mathrm{~cm}$, probably representing part of the Holocene overlying stiff pre-Holocene glacial deposits (? till). Absolue ${ }^{14} \mathrm{C}$ ages are necessary for better age assignment. The short sedimentary record consists of one lithological unit (mainly sandy mud), which is characterized by low to moderate amounts of IRD, low carbonate $(1-5 \%)$, and low organic carbon $(0.3-0.5 \%)$ contents (Fig. 3b). The organic carbon composition is clearly dominated by terrigenous material, as indicated by the very high $\mathrm{C} / \mathrm{N}$ ratios of up to 25 and hydrogen index values of 30-80 (Figs. 3b, 4b). Only in the uppermost $10 \mathrm{~cm}$, may some higher amount of marine organic matter be preserved, as suggested from a $\mathrm{C} / \mathrm{N}$ ratio of 8 and a hydrogen index value of 120 .

Core PS1916 is located on the East Greenland Continental shelf east of Kuhn Island, close to the mouth area of several fjords and in a water depth of $288 \mathrm{~m}$ (Fig. 1). The sediments are of latest Pleistocene to Holocene age and dominated by siliciclastic components. Carbonate contents are $<4 \%$. Organic carbon contents are unusually high, ranging between 0.5 and $2.5 \%$ (Fig. 3d). Based on distinct changes in lithology and other sedimentological parameters, the sequence can be divided in to three different lithological units (Fig. 3d). Unit 1 consists of dark gray, stiff (overconsolidated) sandy mud characterized by maximum occurrence of gravel, a poorly sorted grain-size distribution, carbonate contents of $2.5-4 \%$, and organic carbon contents of $1.3-1.5 \%$. Due to the low hydrogen index (HI) values of $<100$ and $\mathrm{C} / \mathrm{N}$ ratios of $\gg 15$, the organic carbon fraction has a terrigenous source (Figs. 3d, 4c). The sediments of unit 1 are classified as diamicton (? lodgement till). Unit 2 is characterized by an alternation of finely laminated, IRD-poor silty clay (varved clay) and IRD-rich sandy mud (diamicton). Carbonate and organic carbon values range from 0 to $4 \%$ and from 0.4 to $2.6 \%$, respectively (Fig. 3d). In the diamictons, higher amounts of reworked and probably more mature organic matter occur, whereas in the varved clays a mixture of terrigenous and marine, but immature, organic matter is preserved (Fig. 4c). Unit 3 (mainly clayey silt) is characterized by distinctly reduced amounts of IRD, low carbonate contents of $<1 \%$, and still relatively high organic carbon contents of about $1 \%$. The origin of carbonate is mainly marine, as indicated by the occurrence of foraminifera. In the organic carbon fraction, the marine proportion is also increased, as suggested from the decrease of the $\mathrm{C} / \mathrm{N}$ ratios (Fig. 3d) and hydrogen index values of 200-300 (Figs.
$3 \mathrm{~d}, 4 \mathrm{c})$. The glaciomarine sediments of unit 3 are intensely bioturbated.

Assuming the till of unit 1 to be of late Weichselian age (i.e., stable oxygen isotope stage 2), which still has to be proved by AMS ${ }^{14} \mathrm{C}$ dating, mean sedimentation rates would be about $20 \mathrm{~cm} / \mathrm{ka}$ for the postglacial units 2 and 3 . This is in the same range as sedimentation rates calculated for ${ }^{14} \mathrm{C}$-dated East Greenland shelf cores at $65^{\circ} \mathrm{N}$ for the last deglaciation time interval $(10-40 \mathrm{~cm} / \mathrm{ka}$; Mienert and others 1992).

\section{Scoresby Sund record: Core PS1718-1}

Core PS1718 is located in the southern Scoresby Sund, $25 \mathrm{~km}$ west of the mouth of the fjord system in a water depth of $541 \mathrm{~m}$ (Fig. 1). The sediments are of latest Pleistocene (postglacial) to Holocene age and mainly composed of dark grayish brown, gray to olive gray silty clay and sandy mud, with varying amounts of coarse-grained IRD, low carbonate content $(<5 \%)$, and relatively high organic carbon values of up to $1 \%$ (Fig. 3 c; further details in Marienfeld 1991). The sediment sequence can be divided into three lithological units (Fig. 3c): Unit 1 consists of sandy mud characterized by moderate occurrence of IRD, carbonate contents of about $3 \%$, and organic carbon values around $0.8 \%$. The organic carbon is mainly of terrigenous origin as indicated by low HI values $(<100)$ and $\mathrm{C} / \mathrm{N}$ ratios of up to 18 (Figs. 3c, 4d). Unit 2 consists of finely laminated silty clay; IRD is absent and maximum contents of carbonate of about $4 \%$ and organic carbon of about $1 \%$ are recorded. The origin of the organic matter is still mainly terrigenous (Figs. 3c, 4d). Unit 3 (clayey silt to sandy mud) is characterized by generally high amounts of IRD (with maximum values in the lower and uppermost part of the sediment sequence, separated by a distinct minimum of IRD in the middle part), decreased carbonate contents $(1-2 \%)$, and organic carbon contents between 0.3 and $0.7 \%$ (with the maximum values in the middle part of this interval). Based on hydrogen index values of $200-400$ and $C / N$ ratios of 5-10 (Figs. 3c, 4d), significant amounts of the organic matter are of marine origin. The occurrence of foraminifera also indicates that the carbonate is partly of marine origin. Based on AMS ${ }^{14} \mathrm{C}$ dating at core PS1719 (see Fig. 1) and lithostratigraphic correlation (Marienfeld 1991), the boundary between units 2 and 3 has an age of about $10,000 \mathrm{yr} \mathrm{BP}$. This would result in sedimentation rates of about $27 \mathrm{~cm} / \mathrm{ka}$ for the last 10,000 years.

\section{Discussion}

The distinct changes in relative abundances of biogenic and siliciclastic sediment components and grain-size distribution recorded in the sediments from the East Greenland Continental Margin and Scoresby Sund suggest major changes in the depositional history in these environments through late Quaternary times, which can be related to glacial-interglacial variations. 


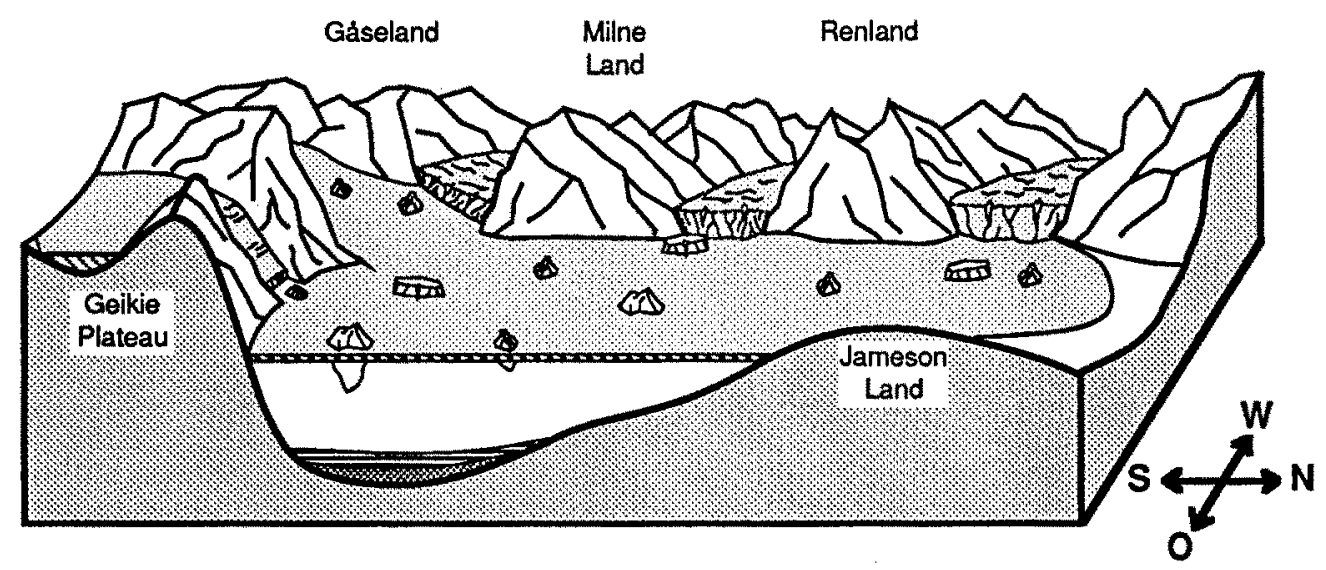

b

\section{RECENT}

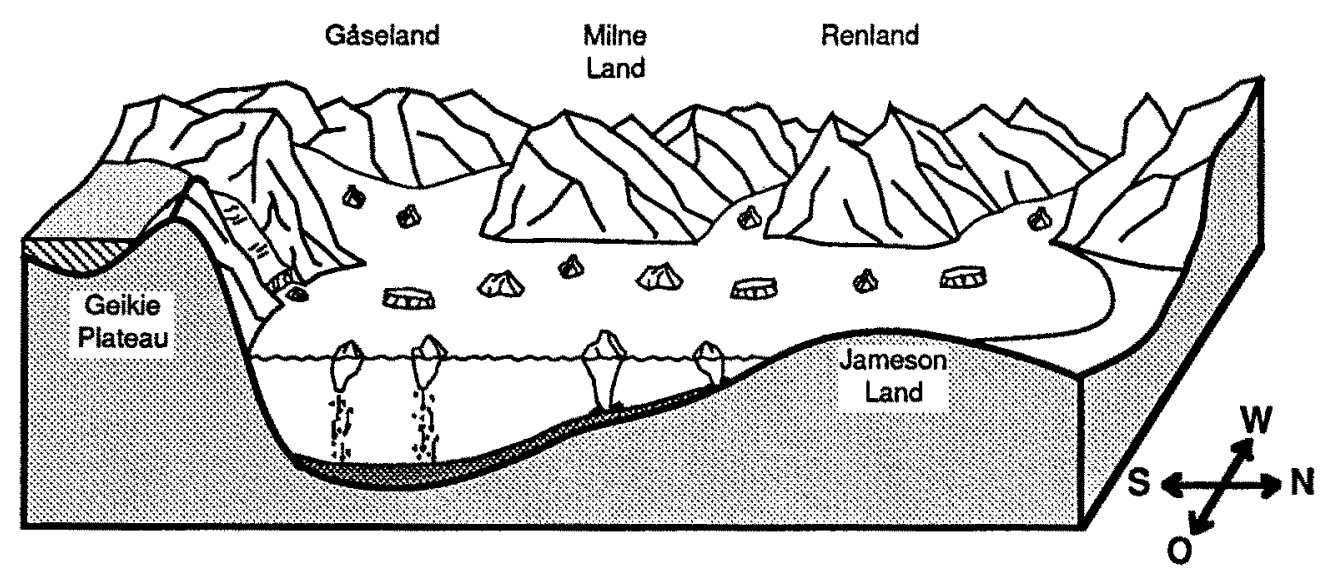

Fig. 5a and b. Depositional model of the Scoresby Sund area for two different late Quaternary time intervals. a The Younger Dryas cooling event. The entire Scoresby Sund is convered by sea ice; finely laminated sediments with a lack of both microfossils and coarse-grained ice-rafted debris are dominant. b The Holocene modern situation. Glacial marine sediments characterized by large amounts of coarse-grained ice-rafted debris and the occasional occurrence of microfossils are typical

During the last glacial maximum conditions, large parts of the high-latitude continental margins were covered by continental ice sheets (e.g., CLIMAP 1981; Vorren and others 1989; Mienert and others 1992; Svendsen and others 1992). The extent of the Greenland Continental Ice Sheet and its change through late Quaternary times is still not yet resolved (e.g., Möller and others 1991 and references therein). In the Greenland Margin area near Scoresby Sund, the extent of continental ice masses was probably smaller during the late Weichselian (oxygen isotope stage 2) glaciation than during older early Weichselian (oxygen isotope stage 5d?) and Saalian (oxygen isotope stage 6) glaciations, as suggested from terrestrial field work data (Hjort 1981; C. Hjort personal communication 1992). On the other hand, the marine geological record from the Scoresby Sund may suggest an extensive late Weichselian (oxygen isotope stage 2) glaciation, since the whole Scoresby Sund was cleaned of its soft bottom sediment by glacial erosion shortly before the Holocene (Dowdeswell and others 1991; Marienfeld 1991). During the last glacial-interglacial transition, the glaciers retreated more or less back to their present extent. This drastic environmental change is clearly documented in the sediments from the East Greenland Continental Margin. Based on a still preliminary stratigraphy, the sediment records are interpreted as follows:

During the last maximum glaciation (the absolute ${ }^{14} \mathrm{C}$ age of which still has to be determined), the valley glaciers draining the continental ice sheet probably reached the East Greenland Shelf at least to the position of core PS1916, as documented in the deposition of the overconsolidated diamicton (lodgement till) (Fig. 3d). From the East Greenland Shelf at $65^{\circ} \mathrm{N}$, Mienert and others (1992) also describe a diamicton (? till) with a ${ }^{14} \mathrm{C}$ age slightly older than 15,000 yr BP, which may suggest grounded ice masses on the East Greenland shelf during the late Wei- 
chselian (oxygen isotope stage 2). During this time of extended glaciation, glaciers delivered large amounts of icerafted debris to the open shelf and closer to the shelf break, and calving rate and iceberg drift were increased, indicated by maximum occurrence and flux (as suggested from high glacial sedimentation rate) of IRD at the upper slope core PS 1726 (Fig. 3a). Large amounts of this material might have derived from the inner Scoresby Sund, where all soft sediments were probably eroded by glaciers (see above).

The end of the glacial interval is indicated by a rapid and drastic decrease in accumulation of IRD at the continental slope (Fig. 3a, core PS1726), caused by the retreat of continental ice masses and glaciers and reduced iceberg drift. On the shelf, the overconsolidated diamicton is overlain by finely laminated (varved) clay-silty clay deposited in a distal proglacial environment (cf., Henrich 1990). The retreat of glaciers was gradual, interrupted by several readvances, as documented in the intercalated horizons of diamictons recorded in the sedimentary sequence of core PS1916 (Fig. 3d). In the lowermost varved clays, maximum contents of organic carbon were recorded. Based on RockEval pyrolysis and $\mathrm{C} / \mathrm{N}$ data, the organic matter is mainly terrigenous; however, a significant amount of hydrogenrich organic material might have been preserved in this shallow-marine restricted environment (Figs. $3 \mathrm{~d}, 4 \mathrm{c}$ ). In the intercalated diamictons, enriched organic carbon values are caused by increased input of reworked organic material, as suggested from the coincidence of high organic carbon values and low hydrogen indices. According to the C/N ratios (Fig. 3d) and Rock-Eval data of core PS1916 (Fig. 4c), the source area and/or source sediment of the organic matter of these intercalated diamictons of unit 2 are probably different from that of the diamicton/till of unit 1 . Based on the hydrogen index-oxygen index diagram (Fig. 4c), the organic matter of the diamicton/till is composed of immature terrigenous material, whereas the material of the intercalated diamictons of unit 2 seems to be more mature. This has to be substantiated, however, by further sedimentological and organic geochemical studies and, especially, by a comparison of the marine record with similar data derived from the investigation of terrestrial sediments from potential source areas on Greenland.

During the last deglaciation, the extent of sea ice also decreased. Whereas during glacial maximum times the East Greenland Continental Margin area was covered by closed sea ice (e.g., CLIMAP 1981), causing distinctly reduced surface-water productivity, the change to more open-ocean conditions with seasonal variations of sea-ice cover resulted in an increase in productivity (Fig. 2; cf., Berner and Wefer 1990; Grobe and others 1990; Mortlock and others 1991; Stein and Stax 1991; Mienert and others 1992). This increased productivity is suggested from increased contents of (marine) organic carbon, radiolarians, sponge spicules, and dinoflagellates recorded in the upper $50 \mathrm{~cm}$ of core PS1726 (Fig. 3a; Nam and others in preparation) The increased flux of organic carbon to the sea floor might have resulted in increased carbonate dissolution causing the disappearance of biogenic carbonate (Fig. 3a; cf., deVernal and others 1992).
In the Scoresby Sund, the sedimentation was controlled by drifting icebergs and meltwater input. Based on Parasound and reflection seismic data as well as ${ }^{14} \mathrm{C}$ dating, all sediments in the fjord were deposited during postglacialHolocene times (Dowdeswell and others 1991; Marienfeld 1991; Uenzelmann-Neben and others 1991). According to the carbonate content and the occurrence of high amounts of reworked terrigenous organic carbon in the lower sequence of core 1718 (unit 1, Fig. 3c), late Pleistocene and/or pre-Quaternary sediments on Jameson Land are a possible source (Houmark-Nielsen and others 1991; Marienfeld 1991). Distinct changes in sedimentation pattern occurred at about $12,000-10,000 \mathrm{yr} \mathrm{BP}$; finely laminated sediments characterized by maximum organic carbon contents and the absence of IRD and microfossils are typical (unit 2, Fig. 3c) and can be correlated throughout the E-W extension of the fjord (Marienfeld 1991). This period may be correlated with the Younger Dryas Cooling Event when the fjord was probably closed by sea ice (Fig. 5a), preventing major iceberg drift and planktonic and benthic life. Under these restricted conditions, perservation rate of organic matter was probably increased.

During the last 10,000 years, bioturbated glaciomarine sediments with varying amounts of IRD are dominant in the sund (and shelf) environment (Fig. 3). Because of high sedimentation rates and shallow water depth, increased amounts of marine (hydrogen-rich) organic matter are preserved in these sediments (Figs. 3c, 4d). In the Scoresby Sund (Fig. 5b), distinctly higher amounts of IRD are recorded in comparison to the shelf environment (Fig. 3b,c), indicating that most of the IRD was already deposited in the fjord systems and only minor amounts reached the open shelf. Maximum values of IRD as well as highest $\mathrm{C} / \mathrm{N}$ ratios of core PS1723 sediments (Fig. 3b) coincide with very light oxygen stable isotope values between 2.0 and $2.8 \%$ and very low carbon stable isotope values between -0.1 and $0.2 \%$ (both measured on planktonic foraminifer $N$. pachyderma sin.), suggesting that meltwater discharge from Greenland has strongly influenced the terrigenous sediment flux off Scoresby Sund during that time (Nam and others in preparation). The meltwater layer was probably very stable and resulted in a poorly ventilated surface water mass (indicated by the light carbon stable isotope values; cf., Vogelsang 1990).

\section{Conclusions}

Sedimentological and organic-geochemical investigations of sediment cores from the East Greenland Continental Margin and the Scoresby Sund give important information about glacial-interglacial variations of high-latitude paleoenvironments and may help to link the terrestrial and deep-sea paleoclimatic records.

The drastic climatic change from glacial maximum to the present interglacial conditions is documented in the sedimentary sequences from upper slope and shelf envi- 
ronments. A facies succession on the shelf from overconsolidated diamicton/lodgement till to alternation of diamictons and varved clay to bioturbated glaciomarine sediments may reflect the gradual retreat of continental ice masses and/or glaciers during the (? early/) late Weichselian glacial-Holocene interglacial transition (termination). This process probably resulted in distinctly decreased flux and deposition of ice-rafted debris in the open shelf-upper slope environment. During this termination, the sea-ice cover also decreased, causing an increase in surface-water productivity, as suggested from increased organic carbon and biogenic opal deposition. During the last 10,000 years, large amounts of ice-rafted debris were probably already trapped in the Scoresby Sund; only minor amounts reached the open shelf.

Acknowledgments For technical assistance, we thank Heike Röben. We sincerely thank C. Hjort (University of Lund, Sweden) and two anonymous reviewers for their constructive suggestions for improvement of the manuscript. This is contribution No. 558 of the Alfred-WegenerInstitute for Polar and Marine Research.

\section{References}

Berner H, Wefer G (1990) Physiographic and biological factors controlling surface sediment distribution in the Fram Strait. In: Bleil U, Thiede J (Eds), Geological History of the Polar Oceans: Arctic versus Antarctic. Dordrecht: Kluwer Academic Publishers, Nato ASI Series C 308:317-335

Bohrmann G, Henrich R, Thiede J (1990) Miocene to Quaternary paleoceanography in the northern Atlantic: Variability in carbonate and biogenic opal accumulation. In: Bleil U, Thiede J (Eds), Geological History of the Polar Oceans: Arctic versus Antarctic. Dordrecht: Kluwer Academic Publishers, Nato ASI Series C 308:647-675.

CLIMAP (1981) Seasonal reconstruction of the earth's surface at the last glacial maximum. Geological Society America Map and Chart Series MC-36.

deVernal A, Bilodeau G, Hillaire-Marcel C, Kassou N(1992) Quantitative assessment of carbonate dissolution in marine sediments from foraminifer linings vs. shell ratios: Davis Strait, northwest North Atlantic. Geology 20:527-530

Dowdeswell JA, Villinger H, Whittington RJ, Marienfeld P (1991) The Quaternary marine record in the Scoresby Sund fjord system, East Greenland: Preliminary results and interpretation. In: Möller P, Hort C, Ingolfsson O (Eds), The Last InterglacialGlacial Cycle: Preliminary Report on the PONAM Fieldwork in Jameson Land and Scoresby Sund, East Greenland. Lundqua Report 33:149-155

Elverhoi A, Dowdeswell JA (1991) Polar North Atlantic Margins (PONAM). ESF Communications 25:16-17

Funder S (1984) Chronology of the last interglacial/glacial cycle in Greenland: First approximation In: Mahaney WC (Ed), Correlation of Quaternary Chronologies. Norwich: Geo Books pp 261279

Gard G, Backman J (1990) Synthesis of Arctic and Subarctic coccolith biochronology and history of North Atlantic drift water influx during the last 500.000 years. In: Bleil U, Thiede J (Eds), Geological History of the Polar Oceans: Arctic versus Antarctic. Dordrecht: Kluwer Academic Publishers, Nato ASI Series C 308: $417-436$

Grobe H, Mackensen A, Hubberten H, Spiess V, Fütterer D (1990) Stable isotope record and late Quaternary sedimentation rates at the Antarctic Continental Margin. In: Bleil U, Thiede J (Eds), Geological History of the Polar Oceans: Arctic versus Antarctic. Dordrecht: Kluwer Academic Publishers, Nato ASI Series C 308: $539-576$

Henrich R (1990) Cycles, rhythms, and events in Quaternary Aretic and Antarctic glaciomarine deposits. In: Bleil U, Thiede $\mathrm{J}$ (Eds), Geological History of the Polar Oceans: Arctic versus Antarctic. Dordrecht: Kluwer Academic Publishers, Nato ASI Series C 308: 213-244

Henrich R, Kassens H, Vogelsang E, Thiede J (1989) Sedimentary facies of glacial-interglacial cycles in the Norwegian Sea during the last $350 \mathrm{ka}$. Marine Geolology 86:283-319

Hjort C (1981) A glacial chronology for northern East Greenland. Boreas 10:259-274

Houmark-Nielsen M, Lovberg K, Mangerud J, Tveranger J (1991) Late Pleistocene stratigraphy and events as revealed by the Flakkerhuk Moraine, Jameson Land, East Greenland. In: Möller P, Hjort C, Ingolfsson O (Eds), The Last Interglacial-Glacial Cycle: Preliminary Report on the PONAM Fieldwork in Jameson Land and Scoresby Sund, East Greenland. Lundqua Report 33:53-64

Marienfeld P (1991) Holozäne Sedimentationsentwicklung im Scoresby Sund, Ost-Grönland. Berichte zur Polarforschung Alfred-Wegener-Institut Bremerhaven 96:162 pp

Mienert J, Andrews JT, Milliman JD (1992) The East Greenland continental margin $\left(65^{\circ} \mathrm{N}\right)$ since the last deglaciation: Changes in seafloor properties and ocean circulation. Marine Geology 106: $217-238$

Möller P, Hort C, Ingolfsson O (1991) The Last Interglacial-Glacial Cycle: Preliminary Report on the PONAM Fieldwork in Jameson Land and Scoresby Sund, East Greenland. Lundqua Report $33: 181 \mathrm{pp}$

Mortlock RA, Charles CD, Froelich PN, Zibello MA, Saltzman J, Hays JD, Burckle LH (1991) Evidence for lower productivity in the Antarctic Ocean during the last glaciation. Nature 351:220222

Müller P (1977) C/N ratios in Pacific deep-sea sediments: Effect of inorganic ammonium and organic nitrogen compounds sorbed by clays. Geochimica et Cosmochimica Acta 41:765-776

Stein R (1991) Accumulation of organic carbon in marine sediments. Lecture Notes in Earth Sciences 34:217 pp

Stein R, Stax R (1991) Late Quaternary organic carbon cycles and paleoproductivity in the Labrador Sea. Geo-Marine Letters 11: $90-95$

Svendsen JI, Mangerud J, Elverhoi A, Solheim A, Schüttenhelm RTE (1992) The Late Weichselian glacial maximum on western Spitsbergen inferred from offshore sediment cores. Marine Geology 104:1-17

Tissot BP, Welte DH (1984) Petroleum Formation and Occurrence. Berlin: Springer-Verlag 699 pp

Uenzelmann-Neben G, Jokat W, Vanneste K (1991) Quaternary sediments in Scoresby Sund, East Greenland: Their distribution as revealed by reflection seismic data. In: Möller P, Hort $C$, Ingolfsson $\mathrm{O}$ (Eds), The Last Interglacial-Glacial Cycle: Preliminary Report on the PONAM Fieldwork in Jameson Land and Scoresby Sund, East Greenland. Lundqua Report 33:139-148

Vogelsang E (1990) Palöozeanographie des Europäischen Nordmeeres an Hand stabiler Kohlenstoff- und Sauerstoffisotope. Berichte SFB 313 Universität Kiel 23:136 pp

Vorren TO, Lebesbye E, Andreassen K, Larsen KB (1989) Glacigenic sediments on a passive continental margin as exemplified by the Barents Sea. Marine Geology 85:251-272 